ORIGINAL ARTICLE

\title{
Association between parent materials and soil attributes along different geological environments in western Pará, Brazil
}

\author{
Gerson Moreira BARROS ${ }^{1}$, Jean Cheyson Barros dos SANTOS $^{1}$, Valdomiro Severino de SOUZA JÚNIOR ${ }^{1 *}$, \\ Elaine Almeida DELARMELINDA ${ }^{1}$, José Coelho de ARAÚJO FILHO², Elis Regina Guimarães CÂMARA ${ }^{1}$ \\ 1 Universidade Federal Rural de Pernambuco, Departamento de Agronomia, Rua Dom Manoel de Medeiros, s/n - Dois irmãos, CEP 52171-900, Recife - PE, Brasil \\ 2 Empresa Brasileira de Pesquisa Agropecuária (EMBRAPA), Unidade de Execução de Pesquisa, Rua Antônio Falcão 402, Boa Viagem, CEP 51020-240, Recife - PE, Brasil \\ * Corresponding author: valdomiro.souzajunior@ufrpe.br
}

\section{ABSTRACT}

The expansion of the agricultural frontier into different geological environments in the west of the state of Pará, northern Brazil, makes it necessary to know the influence of the parent material on local soil attributes. This study aimed to evaluate the influence of different parent materials on five soil profiles along a lithosequence exposed by the BR-163 highway, which runs from north to south through western Pará. The soils were classified, morphologically described and their main horizons sampled for physical, mineralogical and chemical analyses, including the determination of micronutrients, forms of phosphorus and secondary forms of iron. Multivariate analysis was used to group the different soil-parent material associations. The results demonstrated that the diversity of the parent material was a determinant of soil attributes, and was a conditioning factor for the formation of different clay minerals. Multivariate analysis grouped the soils along the lithosequence into a group formed by profiles derived from basic and intermediate igneous rocks, and a second group consisting of profiles derived from sediments and sedimentary rocks. The profile derived from acidic igneous rock showed greater similarity with the profiles derived from sedimentary materials in comparison to those derived from other igneous rocks.

KEYWORDS: soil mineralogy, physical attributes, chemical attributes, multivariate analysis

\section{Associação entre materiais de origem e atributos de solos ao longo de diferentes ambientes geológicos no oeste do Pará, Brasil}

\section{RESUMO}

A expansão da fronteira agrícola em diferentes ambientes geológicos no oeste do Estado do Pará, norte do Brasil, torna necessário conhecer a influência do material de origem sobre os atributos dos solos locais. Este estudo teve como objetivo avaliar a influência de diferentes materiais de origem sobre cinco perfis de solo ao longo de uma litosequência exposta pela rodovia BR-163, que vai de norte a sul pelo oeste do Pará. Os solos foram classificados, morfologicamente descritos e seus principais horizontes amostrados para análises físicas, mineralógicas e químicas, incluindo a determinação de micronutrientes, formas de fósforo e formas secundárias de ferro. Análises multivariadas foram usadas para agrupar as diferentes associaçóes solo-material de origem. Os resultados demonstraram que a diversidade do material de origem foi determinante para os atributos do solo, sendo um fator condicionante para a formação de diferentes argilominerais. A análise multivariada agrupou os solos ao longo da litosequência em um grupo formado por perfis derivados de rochas ígneas básicas e intermediárias, e um segundo grupo constituído por perfis derivados de sedimentos e rochas sedimentares. O perfil derivado de rocha ígnea ácida apresentou maior similaridade com os perfis derivados de materiais sedimentares em comparação àqueles derivados de outras rochas ígneas.

PALAVRAS-CHAVE: mineralogia do solo, atributos físicos, atributos químicos, análises multivariadas

CITE AS: Barros, G. M.; Santos, J. C. B.; Souza Júnior, V. S. S.; Delarmelinda, E. A.; Araújo Filho, J. C.; Câmara, E. R. G. 2018. Association between parent materials and soil attributes along different geological environments in western Pará, Brazil. Acta Amazonica 48: 261-270. 


\section{INTRODUCTION}

The Amazon attracts attention from the world's scientific community due to its environmental and socioeconomic importance (Alencar et al. 2005). Currently, there is a consensus on the necessity for sustainable use of its natural resources in a regional scenario of great agricultural and industrial development (Fearnside, 2001).

The agro-industrial expansion raises questions on the agricultural and environmental relevance of soils in the Eastern Brazilian Amazon (Delarmelinda et al. 2017). However, soil attributes are influenced by their parent materials (Heckman and Rasmussen, 2011) and understanding this influence is critical to determining which areas are most conducive to agricultural production, contributing to the implementation of more sustainable forms of land use (Alencar et al. 2005).

The infrastructural development of the Eastern Brazilian Amazon has been stimulated by the existence of the BR-163 highway, which connects the State of Pará to the midwest of the country. Along this road, rapid agro-industrial development is taking place and, as a consequence, there is a demand for pedological studies along one of the most extensive agricultural frontiers of northern Brazil (Fearnside 2001).

Pedological studies in western Pará are fundamental to the implementation of improved management practices in the soils of the region. Although different parent materials are known to influence certain soil attributes in western Pará (Graça et al. 2015), there are relatively few studies exploring these aspects in this region. Among the few pedological studies published in western Pará, those carried out by Graça et al. (2015) and Oliveira et al. (2016) can be highlighted.

Logistical difficulties in accessing certain remote locations can limit the development of pedological studies. However, as the BR-163 highway lies in the center of an area of expansion of the state's agricultural frontier (Alencar et al. 2005; Brasil 2008), it is logistically favorable for the implementation of soil studies, as it not only enables easy displacement over long distances, but also permits access to profiles derived from different geological environments representative of arable land in western Pará.

In this context, this study aimed to evaluate the main morphological, physical, chemical and mineralogical attributes of five profiles along a lithosequence exposed by the BR-163 highway in western Pará (Eastern Amazon), to observe differences in these attributes associated with variations in parent material.

\section{MATERIAL AND METHODS}

The study area is located in the western region of Pará state, along the BR-163 highway from Cuiabá to Santarém (Figure 1). Five soil profiles were chosen in back-slope positions on the gently undulating local relief, as representative of the local geomorphology. As the position most susceptible to erosion is the center of the slope, this was chosen as the point on the landscape for extraction of each of the five profiles, in order to standardize the effect of relief on the attributes of the sampled soils. The climate of the region is hot and humid, with mean temperatures between 25 and $27^{\circ} \mathrm{C}$ and mean annual rainfall between 1900 and $2400 \mathrm{~mm}$ (Moraes et al. 2005). The five studied profiles were sampled along a lithosequence (Figure 1), and parent materials were defined according to the geological map of Pará (Brasil 2008; João 2013):

Profile 1 (granite from the Maloquinha Intrusive Suite) - Main mineralogy consists of potassic feldspar, plagioclase, quartz, biotite and hornblende. The main accessory minerals are apatite, magnetite, ilmenite, zircon and tourmaline;

Profile 2 (andesite from the Aruri Formation) - Main mineralogy consists of plagioclases, hornblende and biotite. The main accessory minerals are apatite, zircon, iron oxides and titanite;

Profile 3 (shale from the Maecuru Formation) - Main mineralogy consists of quartz. The main accessory mineral is pyrite;

Profile 4 (Penatecaua's diabase) - Main mineralogy consists of plagioclase and pyroxene (augite). The main accessory minerals are iron oxides, hornblende, biotite, apatite, titanite, pyrite, olivine and zircon;

Profile 5 (sediments from the Alter do Chão Formation) - Main mineralogy consists of poorly selected quartz, in addition to clay cuticles immersed in a fully oxidized and silicified thin matrix.

The mineralogical composition of the parent materials was determined with the purpose of relating them to the mineralogical, physical and chemical attributes of the respective soil profiles. The soils were classified according to the World Reference Base for Soil Resources - WRB (FAO 2014). The soils were subdivided into different horizons according to FAO (2014). The soil horizons were sampled, with six replicates of deformed samples for laboratory analysis. The physical, chemical and mineralogical attributes commonly used to assess the agricultural potential of soils were determined (Alvarez et al. 1999; Nascimento et al. 2006; Lima Neto et al. 2009; Delarmelinda et al. 2017). The physical and chemical attributes of the soils were determined according to Embrapa (1997), which included granulometric analyses, clay dispersed in water (CDW), soil $\mathrm{pH}$ in $\mathrm{H}_{2} \mathrm{O}$ and $1 \mathrm{~mol} \mathrm{~L}^{-1} \mathrm{KCl}(1: 2.5), \mathrm{Ca}^{+2} \mathrm{Mg}^{+2}$ and $\mathrm{Al}^{+3}$ extracted with $1 \mathrm{~mol} \mathrm{~L}^{-1} \mathrm{KCl}$ and determined through atomic absorption spectrophotometry, $\mathrm{Na}^{+}, \mathrm{K}^{+}$and P extracted with Mehlich-1 solution and determined through flame spectrophotometry and total organic carbon (TOC), determined through digestion with acidic dichromate and titration with $\mathrm{FeSO}_{4}$. Based on the determinations, the cation exchange capacity (CEC), base saturation (V\%) and $\Delta \mathrm{pH}$ were calculated. 


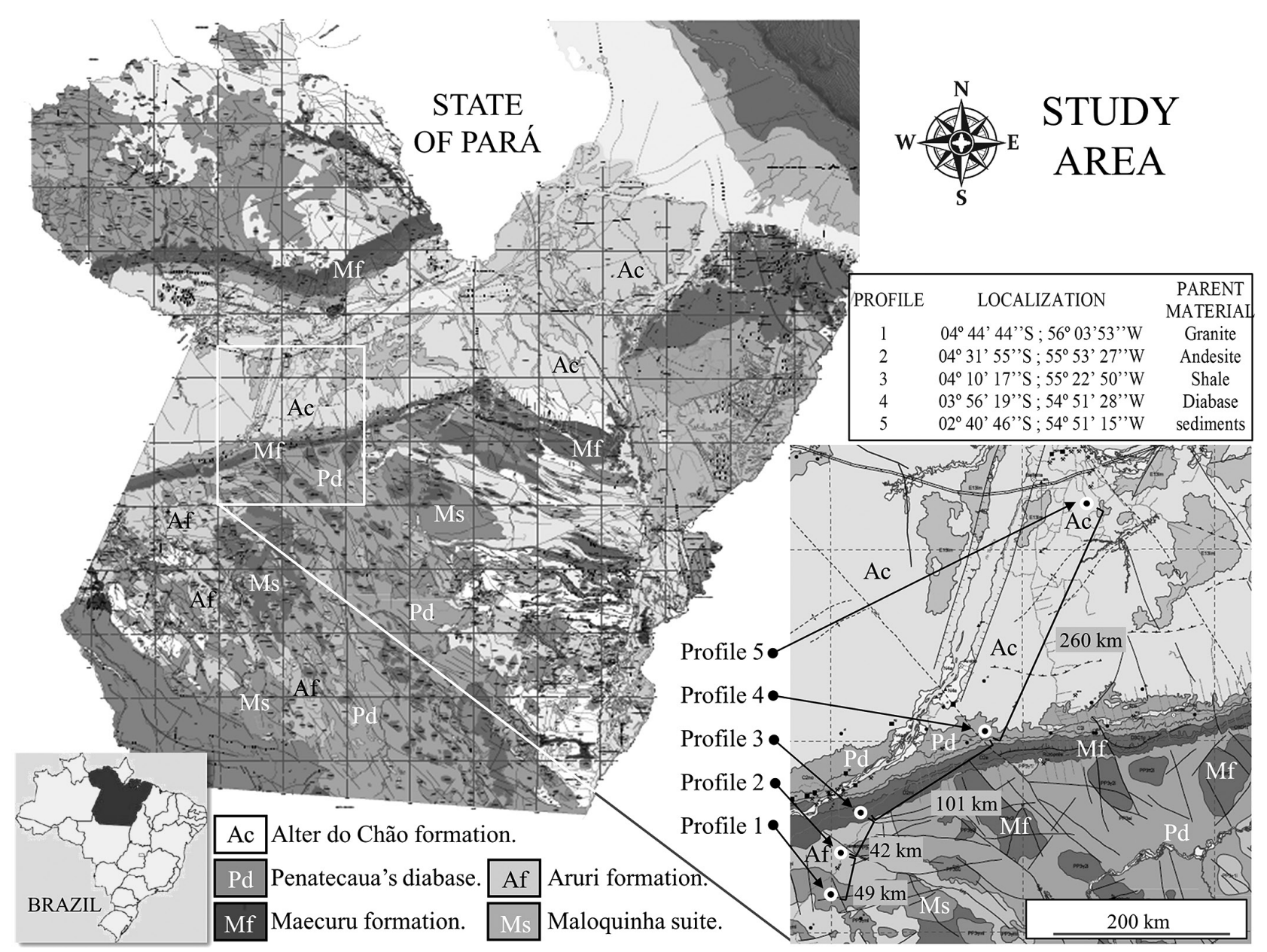

Figure 1. Location of the five profiles in the study area along the BR-163 highway in western Pará state, Brazil.

The remaining phosphorus content (P-rem) was determined according to Alvarez et al. (1999) and total phosphorus (P total) was extracted through sulfuric digestion and determined through a colorimetric method. Mineralogical analyses were performed in the clay fraction $(<2 \mu \mathrm{m})$ in the main horizons. $\mathrm{X}$-ray diffractograms were obtained using an X-ray diffractometer (XRD-6100, Shimadzu, Kyoto, Japan) operating at a tension of $40 \mathrm{Kv}$, with a current of $30 \mathrm{~mA}$ and $\mathrm{CuK \alpha}$ radiation adjusted with graphite monochromator. The scanning amplitude was from 3 to $70^{\circ} 2 \theta$ for the clay fraction, with recording speed of $1.0^{\circ} \theta \mathrm{min}^{-1}$.

The determined forms of Fe were: (1) Fe extracted through sulfuric digestion (Feds); (2) Fe in free form (Fed), quantified using the Sodium Dithionite-Citrate-Bicarbonate (DCB) method, and (3) Fe in the form of low crystallinity (Feo), measured by ammonium oxalate dissolution in the dark (Mehra and Jackson 1960). The concentration of Fe extracts was determined through atomic absorption spectrophotometry. The available micronutrients ( $\mathrm{Fe}, \mathrm{Cu}, \mathrm{Zn}, \mathrm{Mn}$ and $\mathrm{Ni}$ ) were extracted through Mehlich-1 (1;5), and also determined through atomic absorption spectrophotometry.
The main physical and chemical attributes (clay, silt, sand, CEC, V, TOC, Fed, $\mathrm{Mn}, \mathrm{Cu}, \mathrm{Zn}, \mathrm{Ni}$ and $\mathrm{Fe}$ ) were subjected to multivariate statistical analysis using the PAST Paleontological Statistics 3.0 program (Oyvind Hammer, Oslo, Norway). Principal component analysis was used to determine the attributes responsible for the differentiation of soil-parent material associations. Only factors with eigenvalues higher than 1 were selected. In order to group the profiles into clusters according to respective physical and chemical attributes, a cluster analysis was performed using the Bray-Curtis similarity index. Discriminant analysis ( $95 \%$ accuracy) was used in addition to cluster analysis to better understand how the combination of attributes can be used to distinguish the profiles derived from different parent materials.

\section{RESULTS}

\section{Classification and morphological attributes}

Haplic Lixisol (Profile 1), Ferric Ferralsol (Profile 2), Haplic Ferralsol (Profile 3), Ferric Nitisol (Profile 4) and Petroduric Ferralsol (Profile 5) (FAO, 2014) constituted the taxonomic 
classes present in the profiles of the lithosequence (Table 1). The profiles exhibited some morphological variation in color, from reddish to yellowish, and in structure, from blocky to cohesive (Table 1). However, profiles derived from different parent materials also exhibited morphological similarities. Despite their different characteristics, granite and diabase originated soils with morphologically similar subsurface horizons, as observed in the Haplic Lixisol of Profile 1 and Ferric Nitisol of Profile 4 (Table 1). The Nitisol of Profile 4 presented reddish color, contrasting with the yellowish color of the other profiles (Table 1) and the Ferralsol derived from sediments in Profile 5 exhibited a petroduric horizon.

Table 1. Color, depth and presence of granular structures (1), Massive structure (2), Weak structure (3), Moderate structure (4), Strong structure (5), cohesive (Co), Fine (F), Very fine (VF), Subangular blocks (Bls) in the main horizons of the five profiles from a the lithosequence in western Pará, Brazil.

\begin{tabular}{|c|c|c|c|}
\hline Horizon & Depth (m) & Color & Structure \\
\hline \multicolumn{4}{|c|}{ PROFILE 1 - Haplic Lixisol (Granite) } \\
\hline Ap & $0.0-0.1$ & $10 \mathrm{YR} 3 / 2$ & $5 F 1$ \\
\hline BA & $0.1-0.3$ & $10 Y R 4 / 3$ & 4VF Bls \\
\hline Bt1 & $0.3-0.6$ & 7,5 YR 5/6 & $4 \mathrm{VFBls}$ \\
\hline Bt2 & $0.6-1.0$ & 7,5 YR 5/8 & 3-4 VF Bls \\
\hline Bt3 & $1.0-1.6+$ & 10 YR 5/8 & 3-4 VF F Bls \\
\hline \multicolumn{4}{|c|}{ PROFILE 2 - Ferric Ferralsol (Andesite) } \\
\hline A & $0.0-0.2$ & 10YR $4 / 3$ & 5 VF F 1 \\
\hline$A B$ & $0.2-0.4$ & 10YR $4 / 4$ & 4VFF $1 \mathrm{Bls}$ \\
\hline BA & $0.4-0.7$ & 10YR $4 / 5$ & 4VFF Bls \\
\hline Bw1 & $0.7-1.3$ & 10YR 4/5 & 4VF F Bls \\
\hline Bw2 & $1.3-1.8+$ & 10YR $4 / 5$ & 4VFF Bls \\
\hline \multicolumn{4}{|c|}{ PROFILE 3 - Haplic Ferralsol (Shale) } \\
\hline A & $0.0-0.1$ & 10YR $4 / 3$ & 4 VF 1 Bls \\
\hline$A B$ & $0.1-0.2$ & 10YR 5/6 & $4 \mathrm{FBls}$ \\
\hline BA & $0.2-0.5$ & 10YR 5/6 & 4VFFBls \\
\hline Bw1 & $0.5-1.0$ & 10YR 5/6 & 4VF F Bls \\
\hline Bw2 & $1.0-1.5+$ & 10YR 5/6 & 5 VFF Bls \\
\hline \multicolumn{4}{|c|}{ PROFILE 4 - Ferric Nitisol (Diabase) } \\
\hline A & $0.0-0.1$ & $2,5 Y R 3 / 4$ & $5 F 1$ \\
\hline BA & $0.1-0.4$ & $2,5 Y R 3 / 4$ & $5 \mathrm{VFBls}$ \\
\hline Bt1 & $0.4-0.5$ & $2,5 Y R 3 / 4$ & 5 VFF Bls \\
\hline Bt2 & $0.5-1.4$ & $2,5 Y R 4 / 6$ & 5 VFFBls \\
\hline Bt3 & $1.4-1.8+$ & $2,5 Y R 4 / 6$ & 5 VF F Bls \\
\hline \multicolumn{4}{|c|}{ PROFILE 5 - Petroduric Ferralsol (sediments) } \\
\hline A & $0.0-0.1$ & 10YR $4 / 4$ & $4 \mathrm{~F} 1 \mathrm{Bls}$ \\
\hline$A B$ & $0.1-0.3$ & 10YR 4/4 & $4 \mathrm{FBls}$ \\
\hline BA & $0.3-0.5$ & 10YR 4/5 & $2 \mathrm{Co}$ \\
\hline Bw1 & $0.5-0.9$ & 10YR $4 / 5$ & $2 \mathrm{Co}$ \\
\hline Bw2 & $0.9-1.7+$ & 10YR 4/5 & $2 \mathrm{Co}$ \\
\hline
\end{tabular}

\section{Physical and chemical attributes}

The most expressive physical attribute observed in the profiles was the high clay content (Table 2). The soils were very clayey and reached clay contents higher than $900 \mathrm{~g} \mathrm{~kg}^{-1}$, as observed in Profiles 3 and 5. The clay content varied according to the parent material, following the sequence of clayey sediments $>$ shale $>$ diabase $>$ andesite $>$ granite (Table 2). The total sand content decreased with depth (Table 2) and this reduction was even more prominent between the $\mathrm{A}$ horizons and the underlying horizons.

The CEC of these soils were low, despite the high clay content (Table 2), which is characteristic of soils with kaolinitic mineralogy (Marques et al. 2004). Additionally, the values of $\mathrm{pH}$ in water in most profiles ranged from moderately to strongly acidic. Regarding the balance of charges, the values of $\mathrm{pH}$ in water were higher than those determined in $\mathrm{KCl}$, which indicates a predominance of negative electrical charges in the profiles (Table

Table 2. Physical and chemical atributes in the main horizons of five profiles from a lithosequence in western Pará (Brazil), including clay dispersed in water (CDW), cation exchange capacity (CEC), base saturation (V) and total organic carbon (TOC).

\begin{tabular}{|c|c|c|c|c|c|c|c|}
\hline \multirow{2}{*}{ Horizon } & Clay & Silt Sand CDW & pH & & $\mathrm{Al}^{+3} \quad \mathrm{CEC}$ & V & TOC \\
\hline & & $\mathrm{g} \mathrm{kg}^{-1}$ & $\mathrm{H}_{2} \mathrm{O} \quad \mathrm{KCl}$ & & $\mathrm{cmol}_{\mathrm{c}} \mathrm{kg}^{-1}$ & (\%) & $\left(\mathrm{g} \mathrm{kg}^{-1}\right)$ \\
\hline
\end{tabular}

\section{PROFILE 1 - Lixisol (Granite)}

\begin{tabular}{|l|cccc|ccccccc|} 
Ap & 362 & 79 & 560 & 245 & 5.9 & 5.1 & -0.8 & 0.6 & 7.3 & 37 & 23.6 \\
\hline BA & 555 & 4 & 441 & 244 & 5.9 & 5.3 & -0.6 & 0.6 & 4.5 & 42 & 13.1 \\
\hline Bt1 & 607 & 43 & 350 & 246 & 6.3 & 6.0 & -0.3 & 0.6 & 2.8 & 48 & 8.2 \\
\hline Bt2 & 653 & 9 & 339 & 245 & 6.4 & 6.1 & -0.3 & 0.6 & 2.1 & 59 & 2.8 \\
\hline Bt3 & 653 & 70 & 277 & 245 & 6.0 & 6.0 & -1.0 & 0.6 & 2.3 & 50 & 2.4 \\
\hline
\end{tabular}

PROFILE 2 - Ferralsol (Andesite)

\begin{tabular}{|c|c|c|c|c|c|c|c|c|c|c|c|}
\hline A & 649 & 93 & 259 & 208 & 4.3 & 4.1 & -0.2 & 1.4 & 11.0 & 7 & 23.6 \\
\hline$A B$ & 700 & 31 & 270 & 208 & 4.8 & 4.4 & -0.4 & 1.0 & 6.8 & 7 & 13.1 \\
\hline BA & 700 & 31 & 270 & 208 & 4.8 & 4.4 & -0.4 & 0.7 & 6.1 & 7 & 9.6 \\
\hline Bw1 & 697 & 41 & 262 & 208 & 4.7 & 4.5 & -0.2 & 0.5 & 5.5 & 8 & 5.8 \\
\hline Bw2 & 727 & 30 & 265 & 209 & 4.7 & 4.5 & -0.2 & 0.6 & 5.0 & 9 & 5.0 \\
\hline \multicolumn{12}{|c|}{ PROFILE 3 - Ferralsol (Shale) } \\
\hline A & 756 & 99 & 147 & 630 & 4.3 & 3.9 & -0.4 & 1.0 & 10.2 & 12 & 27.7 \\
\hline$A B$ & 780 & 97 & 124 & 434 & 4.3 & 3.9 & -0.4 & 1.2 & 7.6 & 12 & 18.6 \\
\hline BA & 856 & 46 & 98 & 141 & 4.3 & 4.0 & -0.3 & 1.2 & 5.2 & 10 & 12.8 \\
\hline Bw1 & 911 & 2 & 89 & 142 & 4.4 & 4.0 & -0.4 & 1.2 & 3.6 & 13 & 8.7 \\
\hline Bw2 & 902 & 18 & 82 & 141 & 4.9 & 4.1 & -0.8 & 1.1 & 3.8 & 11 & 8.3 \\
\hline \multicolumn{12}{|c|}{ PROFILE 4 - Nitisol (Diabase) } \\
\hline A & 622 & 184 & 195 & 140 & 5.9 & 5.6 & -0.3 & 0.7 & 5.1 & 53 & 14.2 \\
\hline BA & 672 & 173 & 156 & 140 & 6.3 & 5.8 & -0.5 & 0.8 & 3.3 & 53 & 8.6 \\
\hline Bt1 & 718 & 145 & 137 & 140 & 6.6 & 6.0 & -0.6 & 0.8 & 2.5 & 55 & 6.1 \\
\hline Bt2 & 770 & 106 & 125 & 140 & 6.5 & 5.5 & -1.0 & 0.4 & 2.9 & 44 & 4.3 \\
\hline Bt3 & 818 & 49 & 134 & 140 & 6.6 & 5.6 & -1.0 & 0.4 & 1.9 & 49 & 0.9 \\
\hline \multicolumn{12}{|c|}{ PROFILE 5 - Ferralsol (sediments) } \\
\hline A & 846 & 119 & 35 & 552 & 4.1 & 3.7 & -0.4 & 1.1 & 10.8 & 11 & 31.0 \\
\hline$A B$ & 890 & 91 & 20 & 141 & 4.0 & 3.8 & -0.2 & 1.2 & 6.9 & 8 & 18.1 \\
\hline BA & 937 & 46 & 17 & 141 & 4.4 & 3.9 & -0.5 & 1.2 & 4.8 & 9 & 9.2 \\
\hline Bw1 & 895 & 83 & 23 & 142 & 4.7 & 4.0 & -0.7 & 1.2 & 4.2 & 8 & 7.2 \\
\hline Bw2 & 890 & 70 & 40 & 141 & 5.3 & 4.1 & -1.2 & 1.2 & 3.5 & 10 & 4.8 \\
\hline
\end{tabular}


2). The exchangeable acidity in the surface horizons varied from $0.6 \mathrm{cmol}_{\mathrm{c}} \mathrm{kg}^{-1}$, in the Ap horizon of Profile 1, to $1.4 \mathrm{cmol}_{\mathrm{c}} \mathrm{kg}^{-1}$, in the A horizon of Profile 2 (Table 2). Similar trends were also observed in the subsurface horizons. However, the contents of $\mathrm{Al}^{+3}$ in the subsurface horizons of Profiles 2,3 and 5 did not meet the criterion for Alic or Ferralic horizons according to the current World Reference Base for Soil Resources (WRB) (FAO 2014).

\section{Fe contents obtained through different extractors}

There was an increase in Feds with depth in profiles 1, 4 and 5 (Table 3), in association with clay content. Profiles 2 and 5 were characterized as Ferric (FAO 2014). The Feds content in the surface horizons varied from $54.64 \mathrm{~g} \mathrm{~kg}^{-1}$, in the Ap horizon of Profile 1, to $234.11 \mathrm{~g} \mathrm{~kg}^{-1}$, in the A horizon of Profile 2 (Table 3). In the subsurface horizons, the highest content was observed in Profile 2, derived from andesite and rich in ferromagnesian minerals (Mehra and Jackson 1960). High content was also observed in Profile 4, derived from diabase, a basic rock. Profiles 3 and 5, derived from sedimentary materials, showed the lowest contents of Feds in the lithosequence.

There was a large vertical variation of Fed values in the profiles (Table 3). In the surface horizons, the content ranged from $42.03 \mathrm{~g} \mathrm{~kg}^{-1}$, in the Ap horizon of Profile 1, to $170.20 \mathrm{~g}$ $\mathrm{kg}^{-1}$, in the A horizon of Profile 2. In the subsurface horizons, the content ranged from $52.24 \mathrm{~g} \mathrm{~kg}^{-1}$, in the BA horizon of Profile 3, to $171.44 \mathrm{~g} \mathrm{~kg}^{-1}$, in the Bt1 horizon of Profile 4 . The highest values of Feo were observed in Profile 1, derived from granite (Table 5). The highest values of Feo were found in the surface horizons in all the profiles of the lithosequence, which led to a large variation in the Feo/Fed ratio (Table 3), from 0.02, in the A horizons of Profiles 2 and 4, to 0.11 , in the Ap horizon of Profile 1. The iron oxide content in Profiles 2 and 4, derived from andesite and diabase, was relatively high and dominated by crystalline phases, while Profiles 1 , 3 and 5, derived from acidic rock or sedimentary materials, showed low values of Fed (Table 3).

\section{Mineralogical attributes of the clay fraction}

The mineralogical composition of the clay fraction of the soil along the lithosequence was constituted by kaolinite, gibbsite, quartz and goethite, besides hematite in the profiles derived from andesite and diabase (Figure 2). Kaolinite was identified by the presence of peaks at 0.72 and 0.35 $\mathrm{nm}$, gibbsite by a peak at $0.48 \mathrm{~nm}$, goethite at $0.41 \mathrm{~nm}$, quartz at $0.33 \mathrm{~nm}$, and hematite at 0.26 and $0.25 \mathrm{~nm}$. The diffractograms revealed the occurrence of hematite in Profiles 2 and 4 (Figure 2), although the hue of Profile 2 (10 YR 4/3) indicated an absence of hematite (Table 1).

\section{Micronutrients}

The diversity of parent materials along the lithosequence was also reflected in variable values of micronutrients (Table 4). For $\mathrm{Mn}$, the highest content was observed in Profile 1, derived
Table 3. Fe content obtained by sulfuric digestion (Feds), Sodium DithioniteCitrate-Bicarbonate (Fed) and ammonium oxalate dissolution in the dark (Feo) in five profiles from a lithosequence in western Pará, Brazil.

\begin{tabular}{|c|c|c|c|c|}
\hline \multirow{2}{*}{ Horizon } & Feds & Fed & Feo & \multirow{2}{*}{ Feo/Fed } \\
\hline & \multicolumn{3}{|c|}{$\mathrm{g} \mathrm{kg}^{-1}$} & \\
\hline \multicolumn{5}{|c|}{ PROFILE 1 - Lixisol (Granite) } \\
\hline Ap & 54.64 & 42.03 & 4.81 & 0.11 \\
\hline Bt1 & 80.97 & 60.00 & 0.94 & 0.02 \\
\hline Bt3 & 93.18 & 76.46 & 0.62 & 0.01 \\
\hline \multicolumn{5}{|c|}{ PROFILE 2 - Ferralsol (Andesite) } \\
\hline A & 234.11 & 170.20 & 2.66 & 0.02 \\
\hline BA & 241.37 & 150.92 & 1.77 & 0.01 \\
\hline Bw2 & 229.69 & 164.93 & 0.83 & 0.01 \\
\hline \multicolumn{5}{|c|}{ PROFILE 3 - Ferralsol (Shale) } \\
\hline A & 55.21 & 48.92 & 4.66 & 0.10 \\
\hline BA & 55.18 & 52.24 & 1.79 & 0.03 \\
\hline Bw2 & 52.55 & 48.32 & 0.41 & 0.01 \\
\hline \multicolumn{5}{|c|}{ PROFILE 4 - Nitisol (Diabase) } \\
\hline A & 184.75 & 148.18 & 2.65 & 0.02 \\
\hline Bt1 & 194.91 & 171.44 & 2.59 & 0.02 \\
\hline $\mathrm{Cr} 2$ & 232.57 & 181.97 & 1.78 & 0.01 \\
\hline \multicolumn{5}{|c|}{ PROFILE 5 - Ferralsol (sediments) } \\
\hline A & 68.11 & 60.23 & 1.81 & 0.03 \\
\hline $\mathrm{BA}$ & 75.18 & 63.77 & 0.81 & 0.01 \\
\hline Bw2 & 73.93 & 62.34 & 0.31 & 0.01 \\
\hline
\end{tabular}

Table 4. Micronutrient contents in five profiles from a lithosequence in western Pará, Brazil.

\begin{tabular}{lccccc}
\hline & \multicolumn{5}{c}{ Element } \\
\cline { 2 - 5 } Horizon & $\mathrm{Mn}$ & $\mathrm{Cu}$ & $\mathrm{Zn}$ & $\mathrm{Ni}$ & $\mathrm{Fe}$ \\
\cline { 2 - 5 } & \multicolumn{4}{c}{$\mathrm{mg} \mathrm{kg}^{-1}$} \\
\hline
\end{tabular}

PROFILE 1 - Lixisol (Granite)

$\begin{array}{llllll}\text { Ap } & 213.10 & 0.82 & 0.13 & 0.68 & 27.16 \\ \text { BA } & 79.17 & 1.06 & 0.11 & 0.60 & 6.06\end{array}$

PROFILE 2 - Ferralsol (Andesite)

$\begin{array}{llllll}A & 7.62 & 2.15 & 0.09 & 0.25 & 27.97 \\ A B & 5.03 & 1.90 & 0.04 & 0.17 & 14.98\end{array}$

PROFILE 3 - Ferralsol (Shale)

\begin{tabular}{lccccc} 
A & 7.09 & 0.46 & 0.15 & 0.33 & 165.82 \\
\hline$A B$ & 2.45 & 0.30 & 0.06 & 0.23 & 121.68 \\
\hline PROFILE 4 & Nitisol (Diabase) & & & & \\
\hline A & 189.11 & 6.12 & 0.59 & 2.43 & 13.61 \\
BA & 120.73 & 5.06 & 0.08 & 0.32 & 24.22
\end{tabular}

PROFILE 5 - Ferralsol (sediments)

\begin{tabular}{llllll}
$A$ & 15.97 & 0.61 & 0.21 & 0.34 & 83.99 \\
$A B$ & 2.70 & 0.51 & 0.05 & 0.13 & 51.39 \\
\hline
\end{tabular}



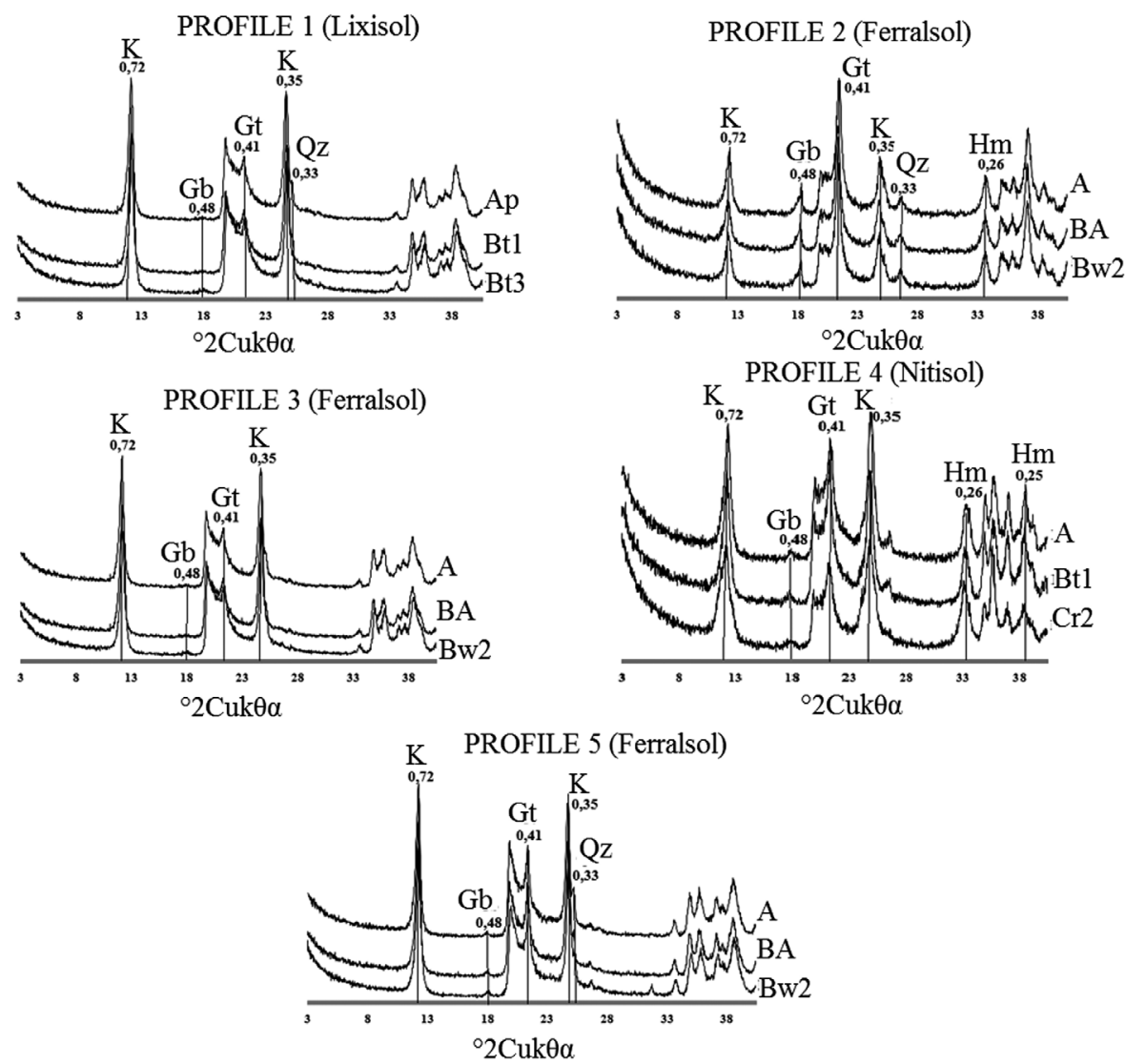

Figure 2. Diffractograms of the clay fraction without treatment of Profile 1 (horizons Ap, Bt1 and Bt3); Profile 2 (horizons A, BA and Bw2); Profile 3 (horizons A, BA and Bw2); Profile 4 (horizons A, Bt1 and (r2); Profile 5 (horizons A, BA and Bw2). Values of reflections in nanometers.

from granite. In the subsurface, the highest content was found in Profile 4, derived from diabase (Table 4). The highest $\mathrm{Cu}$ content was observed in the surface horizon of Profile 2, derived from andesite (Table 4). With the exception of Profile 4, derived from diabase, the profiles showed a reduction in $\mathrm{Cu}$ content as depth increased. The highest $\mathrm{Zn}$ content was also observed in Profile 4, confirming the importance of the composition of the parent material, which is rich in mafic minerals, for the supply of elements during evolution of the regolith.

$\mathrm{Ni}$ content followed the same trend as $\mathrm{Zn}$ content, with higher values in the surface horizons and a decrease with depth in all profiles. The highest $\mathrm{Fe}$ content was observed in the surface horizons of Profile 3, derived from shale (Table 4). The micronutrient content of soils in the lithosequence followed the decreasing order of $\mathrm{Fe}>\mathrm{Mn}>\mathrm{Cu}>\mathrm{Ni}>\mathrm{Zn}$ in surface and subsurface horizons (Table 4) except for Profiles 1 and 4, these being derived from clayey sediments, which showed higher $\mathrm{Fe}$ content in comparison to Mn (Table 4).

\section{Forms of phosphorus in the soil}

The $P$ content in the studied profiles was low (Table 5), as observed by Rovers et al. (1983) in similar soils. The P total in the surface horizons varied from $60 \mathrm{mg} \mathrm{kg}^{-1}$, in the A horizon of Profile 3,
Table 5. Phosphorus total (P total), available phosphorus (P Meh) and remaining phosphorus (P-rem) in the superficial horizons of five profiles in western Pará, Brazil.

\begin{tabular}{lrrr}
\hline \multirow{2}{*}{ Horizon } & Ptotal & P Meh & P-rem \\
\cline { 2 - 3 } & $\mathrm{mg} \mathrm{kg}^{-1}$ & \\
\hline
\end{tabular}

PROFILE 1 - Lixisol (Granite)

\begin{tabular}{lrrl} 
Ap & 160.0 & 0.8 & 7.1 \\
BA & 110.0 & 0.2 & 6.0 \\
PROFILE 2 - Ferralsol (Andesite) & & \\
\hline A & 1950.0 & 4.6 & 3.4 \\
AB & 2380.0 & 4.8 & 2.9
\end{tabular}

PROFILE 3 - Ferralsol (Shale)

\begin{tabular}{lccc}
\hline A & 60.0 & 1.2 & 4.8 \\
\hline AB & 50.0 & 1.0 & 4.4 \\
PROFILE 4 - Nitisol (Diabase) & & & \\
A & 90.0 & 1.2 & 5.8 \\
\hline BA & 90.0 & 1.0 & 5.2 \\
\hline PROFILE 5 - Ferralsol (sediments) & & \\
A & 170.0 & 1.2 & 5.4 \\
\hline AB & 70.0 & 0.6 & 4.8 \\
\hline
\end{tabular}


to $1950 \mathrm{mg} \mathrm{kg}^{-1}$, in the A horizon of Profile 2 (Table 5). In the underlying horizons, $\mathrm{P}$ total varied from $50 \mathrm{mg} \mathrm{kg}^{-1}$, in the $\mathrm{AB}$ horizon of Profile 3, to $2380 \mathrm{mg} \mathrm{kg}^{-1}$, in the AB horizon of Profile 2. There was a wide amplitude of P-rem data (Table 5). In surface horizons, the values varied from $3.4 \mathrm{mg} \mathrm{kg}^{-1}$, in the A horizon of Profile 2, to $7.1 \mathrm{mg} \mathrm{kg}^{-1}$, in the Ap horizon of Profile 1, while in horizons immediately below the A horizons it varied from 2.9 $\mathrm{mg} \mathrm{kg}^{-1}$, in the $\mathrm{AB}$ horizon of Profile 2, to $6.0 \mathrm{mg} \mathrm{kg}^{-1}$, in the $\mathrm{BA}$ horizon of Profile 1. The P Meh content varied from $0.8 \mathrm{mg} \mathrm{kg}^{-1}$ in the Ap horizon of Profile 1, derived from an acidic igneous rock, to $4.6 \mathrm{mg} \mathrm{kg}^{-1}$ in the A horizon of Profile 2, this being derived from an igneous rock of intermediate composition (Table 5).

\section{Multivariate statistical analysis}

Cluster analysis with $80 \%$ similarity showed a group formed by Profiles 2 and 4, derived from basic and intermediate igneous rocks, and a group formed by Profiles 3 and 5, derived from clayey sediments and sedimentary rock (Figure 3). Profile 1 , derived from acidic igneous rock, showed more similarity with Profiles 3 and 5, in comparison to Profiles 2 and 4 . The discriminant analysis corroborated the results obtained in the cluster analysis, with Profiles 2 and 4 and Profiles 3 and 5 forming distinct groups (Figure 4). In the PCA analysis, principal component 1 had an eigenvalue of 7.43 , accounting for $62 \%$ of the total variance. Principal component 2 had an eigenvalue of 2.84 , accounting for $24 \%$ of the total variance. Component 1 was best represented by the attributes of $\mathrm{Ni}$ (0.95); $\mathrm{Mn}(0.92) ; \mathrm{V}(\%)$ (0.91) and $\mathrm{Cu}(0.86)$. Component 2 was best represented by the attributes of clay $(0.81)$; silt (0.75), $\mathrm{Zn}(0.54)$ and $\mathrm{Fe}(0.40)$. Factor 1 (62\%) was negatively loaded for the attributes more associated with Profiles 3 and 5 , such as clay, CEC and TOC, and positively loaded for the attributes associated with Profiles 2 and 4, such as silt, sand and micronutrients (Figure 5).

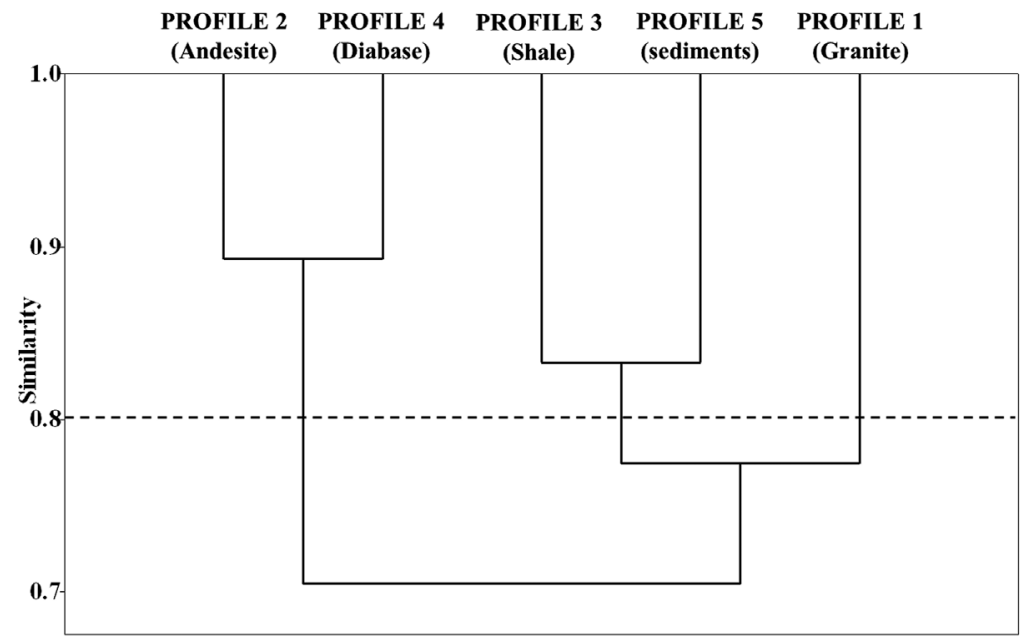

Figure 3. Cluster analyses of the five profiles along the lithosequence in western Pará state, Brazil.

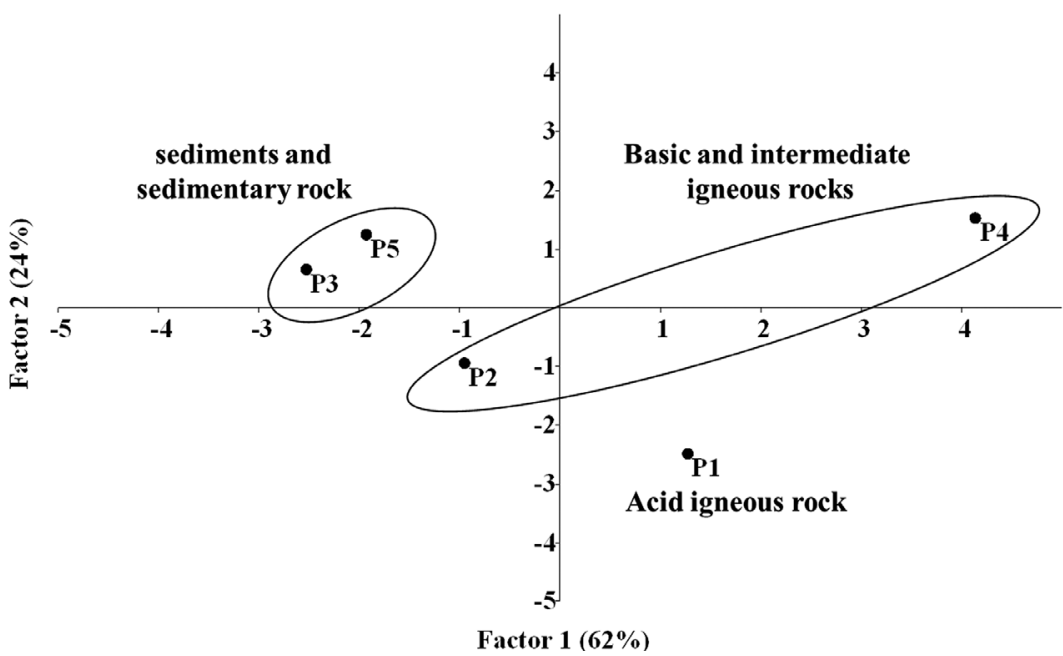

Figure 4. Discriminant analysis of the groups formed in the cluster analyses of samples from a lithosequence along BR-163 highway in western Pará state, Brazil. 


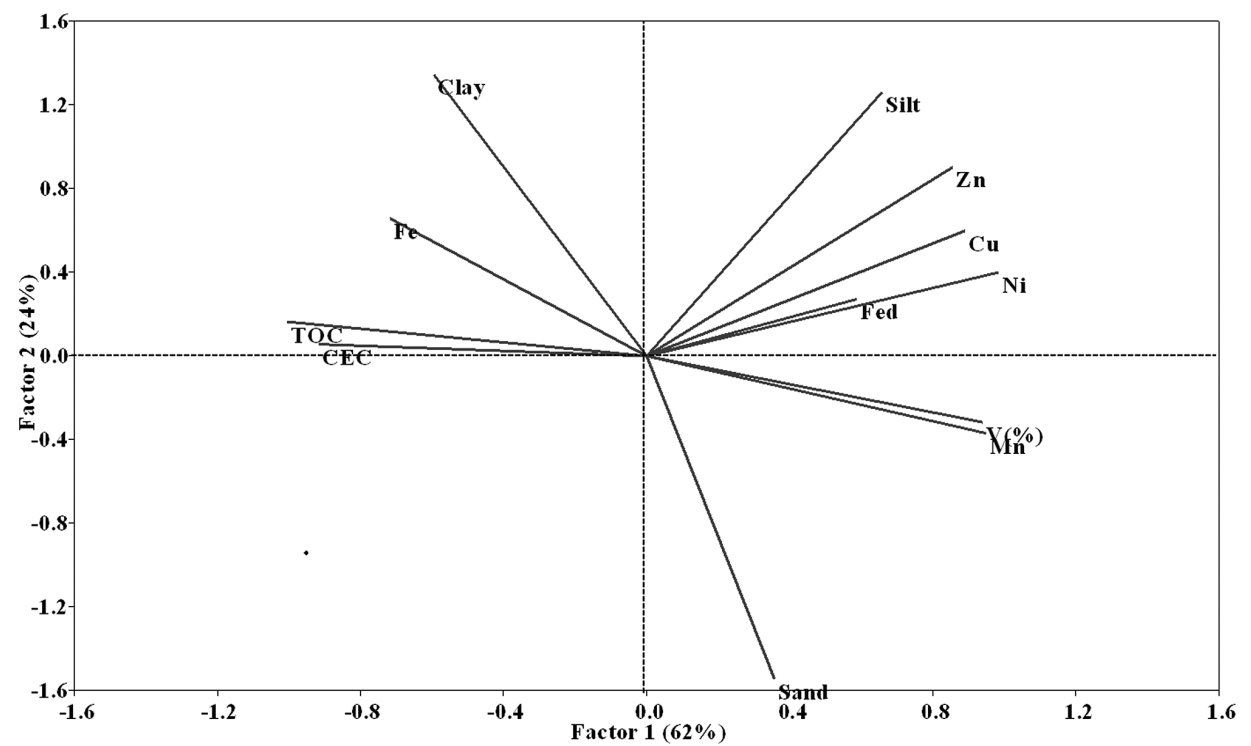

Figure 5. Loadings of the main attributes on the significant factors for five profiles from a lithosequence along BR-163 highway in western Pará, Brazil.

\section{DISCUSSION}

The soils and their respective parent materials contemplated in this study can be extrapolated to the state of Pará and a large part of the northern region of Brazil. In addition, the morphological variations detected between the profiles were mainly associated with the diversity of parent materials along the lithosequence. For example, the reddish hue of the Ferric Nitisol of Profile 4 provides clear evidence of the influence of the parent material-climate relationship during soil evolution. The diabase saprolite, rich in ferromagnesian minerals, gives rise to reddish soils under weathering conditions favorable to intense formation of hematite (Anda et al. 2008).

Another process conditioned by the interaction between climate and parent material is the development of cohesive character, as observed in Profile 5. This process occurs under natural conditions in soils derived from sediments under strong weathering conditions, specially in transitional mineral horizons, $\mathrm{AB}$ or $\mathrm{BA}$, possibly reaching the $\mathrm{Bw}$ or $\mathrm{Bt}$ horizon (Lima Neto et al. 2009). In addition, the low values found for CDW are consistent with kaolinitic mineralogical composition, characteristic of tropical soils (Marques et al. 2004).

The decrease of total sand content with depth is probably associated with the transport and deposition of the coarse fraction on the surface (Anda et al. 2008). This process may also explain the abrupt decrease in the silt fraction between the surface and subsurface horizons of the five profiles. The acidity of the surface horizons, which is a limiting factor for cultivation in the studied soils, is due to the high weathering rates of easily weatherable minerals and the excessive leaching of the resulting bases (Soares et al. 2005), which was also reflected in the low values obtained for base saturation.
The predominance of negative charges in Amazonian soils is highly influenced by the functional groups of organic matter (Bernini et al. 2013). Humidified organic matter (represented by TOC) increased the density of negative electrical charge in the more superficial horizons of the studied profiles, specially in Profiles 3 and 5, which were derived from sedimentary materials. Humidified organic matter is even more important for the CEC of soils due to the low density of negative charge originating from the 1:1 secondary phyllosilicates in the clay fraction, such as kaolinite (Gabos et al. 2014).

The association of Feds with clay content in the samples was more expressive in Lixisol and Nitisol, since these orders, particularly Lixisol, exhibit a more accentuated textural gradient (Lima Neto et al. 2009). However, since these are secondary forms of Fe, the vertical distribution of Fed was strongly influenced by the action of pedogenetic processes, such as argilluviation (Gabos et al. 2014).

Associations between $\mathrm{Fe}$ and organic matter described by Lima Neto et al. (2009) limit the crystallinity of secondary iron oxides and probably resulted in the increase in Feo values in surface horizons with higher TOC values, which, in turn, resulted in a large variation in the Feo/Fed ratio in the surface horizons. The decrease in the Feo/Fed ratio with profile depth is associated, among other factors, with the transformation of ferrihydrite into more crystalline Fe oxides, like hematite (Thaymuang et al. 2013). The presence of hematite in soils with a hue of 10YR 4/3 (Table 1) suggests that the low content of this oxide, as well as the occurrence of its characteristic reddish color, may have been masked by the presence of organic matter (Anda et al. 2008). On the other hand, the presence of hematite in Profile 4 seems to be much more effective, due to the nature of the rock of origin (diabase). 
It is interesting to note the presence of kaolinite in coexistence with gibbsite in the samples, such that the presence of $\mathrm{Al}$ oxides is conditioned to the low activity of silica (Bernini et al. 2013). Kaolinite persists in many environments as a relic of the initial cycles of weathering or comes from poorly drained sites distributed in the microstructure of the soil (White and Dixon 2002). In a study on the relationship between biological activity and soil mineralogy, high levels of silicon occurred, even under strong weathering conditions, and the presence and stabilization of kaolinite in surface layers was attributed to the biocycling of Si under Amazonian vegetation (Lucas et al. 1997).

The content of micronutrients such as $\mathrm{Ni}$ and $\mathrm{Fe}$ in the soil are mainly due to the nature of the parent material (Rovers et al. 1983). However, the higher values of other micronutrients such as Mn in our surface horizons may be associated with the increment of oxides of low crystallinity, which is corroborated by the values for Feo, an indication of the low degree of crystallinity of the Fe (Oliveira and Nascimento 2006).

In acidic soils, under physicochemical conditions similar to those of the present study, a large portion of the $\mathrm{Zn}$ may be unavailable due to the formation of complexes with organic compounds (Nascimento et al. 2006). However, although micronutrients like $\mathrm{Cu}$ and $\mathrm{Zn}$ can form strong complexes with organic compounds, they are not stable for long periods of surface weathering (Marques et al. 2004).

In soils in the central Brazilian Cerrado biome, $\mathrm{Cu}$ content in surface horizons can be replenished by atmospheric deposition in $<16,000$ years, while for $\mathrm{Zn}$ this value is approximately 3,000 years, yet for $\mathrm{Mn}$ it is approximately 420,000 years, all of which are relatively short time spans if we consider that the soils have been subject to weathering since the Cretaceous Period (Marques et al. 2004). These characteristics may be shared with soils in the Eastern Amazon, given the proximity between the Amazon Basin and the Brazilian Central Plateau.

Low values of $\mathrm{P}$ are common in highly weathered soils of the Amazon Basin (Delarmelinda et al. 2017). Accordingly, there was a tendency for lower values of P-rem with an increase in clay content in the samples, emphasizing the great absorption of $\mathrm{P}$ in the subsurface.

The group formed by Profiles 2 and 4 in the cluster analysis was due to similarities in the mineralogical composition existing between the lithotypes originating both profiles. The diabase and andesite of the region exhibit contents of easily weatherable minerals, such as plagioclases, biotite, pyroxenes and amphiboles, which are naturally higher than the values described for shale and the sediments that originated Profiles 3 and 5 (Brasil 2008). The granite that originated Profile 1 has a primary mineralogical composition with a relatively higher content of minerals that are more resistant to weathering, such as quartz and potassium feldspars (Brasil 2008). This mineralogical composition shares more similarity with the group formed by Profiles 3 and 5 in comparison to the group formed by Profiles 2 and 4 .

The discriminant analysis demonstrated that the groups were more influenced by the type of parent material, especially the primary mineralogical composition, than by the respective taxonomic classes of the soils. The Ferralsols in Profiles 3 and 5 , derived from sedimentary materials, were grouped apart from the Ferralsol derived from igneous rock in Profile 2. In addition, the Ferric Ferralsol in Profile 2 showed greater similarity with the Ferric Nitisol derived from basic igneous rock in Profile 4.

The different multivariate analyses presented consistent results and grouped the profiles into the same clusters. As a consequence, the PCA analysis separated the samples according to negatively loaded attributes, associated with the profiles derived from sedimentary materials and positively loaded attributes related to the profiles derived from diabase and andesite.

The association of attributes $\mathrm{V}(\%)$, Fed and micronutrients with Profiles 2 and 4 was due to the contribution of the mafic mineralogical composition of the respective originating lithotypes to the attributes of these soils (Brasil 2008). The association of CEC, clay and TOC attributes with Profiles 3 and 5 demonstrated the contribution of humified organic matter present in the clay fraction to the CEC of these Ferralsols derived from sedimentary materials.

The results obtained in this study indicate that attributes such as macro and micronutrient contents, clay content and type of clay minerals increase the agricultural potential of the soils along the lithosequence in western Pará. In addition, the types of secondary forms of $\mathrm{Fe}$ and their relationships with the available phosphorus are attributes that limit the productivity of these soils. However, the most modern agricultural techniques developed for soils of northern and mid-western Brazil can compensate these limitations.

\section{CONCLUSIONS}

The diversity of the parent material influenced the physical and chemical attributes of the soils along a lithosequence in western Pará. Attributes such as macro and micronutrient contents, clay content and type of clay minerals increase the agricultural potential, while the secondary forms of $\mathrm{Fe}$ and their relationships to the available phosphorus limit the productivity of these soils. The diversity of the parent materials also contributed to variations in the morphological and mineralogical attributes of the soils along the lithosequence. The profiles derived from andesite and diabase exhibited more reddish hues and the presence of hematite in the clay fraction, differing from the other profiles derived from acidic rock and sedimentary materials. In all profiles, kaolinite coexisted with gibbsite in the clay fraction, providing evidence of the occurrence of monosiallitization and allitization in the soils, 
which may be associated with strong weathering conditions, regardless of the parent material. The attributes of the profiles along the lithosequence make it possible to distinguish between soil derived from acidic igneous rock and groups formed by soils derived from basic/intermediate igneous rocks and sediments/sedimentary rocks.

\section{ACKNOWLEDGMENTS}

To Conselho Nacional de Desenvolvimento Científico e Tecnológico $(\mathrm{CNPq})$ for the financial support through Edital Universal - MCTI/CNPq\# 12/2016 (Proc. 304642/2016-9).

\section{REFERENCES}

Alencar, A.A C.; Micol, L J A.; Reid, J.; Amend, M.R.; Oliveira, M.; Zeidemann, V. K.; Sousa Júnior, W. C. A. 2005. Pavimentação da BR 163 e os desafios à sustentabilidade: uma análise econômica, social e ambiental. 1st ed. Conservation Srategy Found of Brazil, Belo Horizonte. 29p.

Alvarez, V.V.H.; Novais, R.F.; Barros, N.F.; Cantarutti, R.B.; Lopes, A.S. 1999. Interpretação dos resultados das análises de solos. In: Ribeiro, A.C.; Guimarães, P.T.G.; Alvarez, V.V.H. (Ed.). Recomendaçôes para o uso de corretivos e fertilizantes em Minas Gerais. v.1. Sociedade Brasileira de Ciência do Solo, Viçosa, p.25-32.

Anda, M.; Shamshuddin, J.; Fauziah, C.I.; Syed Omar, S.R. 2008. Mineralogy and factors controlling charge development of three oxisols developed from different parent materials. Geoderma, 143: 53-167.

Bernini, T.A.; Marcos, G.P.; Anjos, L.H.C.; Perez, D.V.; Fontana, A.; Calderano, S.B.; Wadt, P.G.S. 2013. Quantification of aluminium in soil of the Solimóes formation, Acre state, Brazil. Revista Brasileira de Ciência do Solo, 37: 1587-1598.

Brasil. 2008. Folha SA. 21-Santarém. Geologia, geomorfologia, pedologia, vegetação e uso potencial da terra. 3 da. ed. DNPM, Rio de Janeiro, 280p.

Delarmelinda, E.A.; Souza Júnior, V.S.; Wadt, P.G.S.; Deng, Y.; Campos, M.C.C.; Câmara, E.R.G. 2017. Soil-landscape relationship in a chronosequence of the middle Madeira River in southwestern Amazon, Brazil. Catena, 149: 199-208.

EMBRAPA - Empresa Brasileira de Pesquisa Agropecuária. 1997. Manual de métodos de análise de solo. 2da. ed. Centro Nacional de Pesquisa de Solos, Rio de Janeiro, 212p.

FAO - Food and agriculture Organization of the United Nations. 2014. World reference base for soil resources 2014. 2nd. ed. Food and Agriculture Organization of the United Nations, Rome, 203p.

Gabos, M.B.; Alleoni, L.R.F.; Abreu, C.A. 2014. Background levels of selenium in some selected Brazilian tropical soils. Journal of Geochemical Exploration, 145: 35-39.

Graça, C.H.; Passig, F.H.; Kelniar, A.R.; Piza, M.A.; Carvalho, K.Q.; Arantes, E.J. 2015. Multitemporal analysis of estimated soil loss for the river Mourão watershed, Paraná-Brazil. Brazilian Journal of Biology, 75: 120-130.
Heckman, K.; Rasmussen, C. 2011. Lithologic controls on regolith weathering and mass flux in forested ecosystems of the southwestern USA. Geoderma, 164: 99-111.

João, X.S.J. 2013. Geodiversidade do estado do Pará. 1st ed. CPRM, Belém, 258p.

Lima Neto, J.A.; Ribeiro, M.R.; Corrêa, M.M.; Souza Júnior, V.S.; Lima, J.F.W.F.; Ferreira, R.F.A.L. 2009. Caracterização e gênese do caráter coeso em Latossolos Amarelos e Argissolos dos tabuleiros costeiros do Estado de Alagoas. Revista Brasileira de Ciência do Solo, 33: 1001-1011.

Lucas, Y.; Luizão, F.J.; Chauvel, A.; Rouiller, J.; Nahon, D. 1993. The relation between biological activity of the rain forest and mineral composition of soils. Science, 260: 521-523.

Marques, J.J.; Schulze, D.G.; Curi, N.; Mertzman, A. 2004. Trace Element Geochemistry in Brazilian Cerrado soils. Geoderma, 121: 31-43.

Mehra, O.P.; Jackson, M.L. 1960. Iron oxide removal from soils and clays by dithionite-citrate system buffered with sodium bicarbonate. Clay and Clay Minerals, 35: 317-327.

Moraes, B.C.; Costa, J.M.; Costa, A.C.L. Costa, M.H. 2005. Variação espacial e temporal da precipitação no estado do Pará. Acta Amazonica, 35: 207- 214

Nascimento, C.W.A.; Oliveira, A.B.; Ribeiro, M.R.; Melo, E.E.C. 2006. Distribution and Availability of zinc and copper in benchmark soils of Pernambuco State, Brazil. Communications in Soil Science and Plant Analysis, 37: 109-125.

Oliveira, M.P.; Dalposso, G.H.; Espires, C.R.; Faria, J.F. 2016. Mapas temáticos de componentes principais para caracterização de propriedades químicas do solo. Engenharia na agricultura, 23: 529-540.

Oliveira, A.B.; Nascimento, C.W.A. 2006. Formas de Manganês e Ferro em Solos de Referência de Pernambuco. Revista Brasileira de Ciência do Solo, 30: 99-110.

Rovers, H.; Camargo, O.A.; Valadares, J.M.A.S. 1983. Níquel total e solúvel em DTPA em solos do Estado de São Paulo. Revista Brasileira de Ciência do Solo, 7: 217-220.

Soares, M.R.; Alleoni, L.R.F.; Vidal-Torrado, P.; Cooper, M. 2005. Mineralogy and ion Exchange properties of the particle size fractions of some Brazilian soils in tropical humid areas. Geoderma, 125: 355-367.

Thaymuang, W.; Kheoruenromne, I.; Suddhipraharn, A.; Sparks, D. 2013. The role of mineralogy in organic matter stabilization in tropical soils. Soil Science, 178: 308-315.

White, G.N.; Dixon, J.B. Kaolin-Serpentine minerals. 2002. In. Amonette, J. E.; Bleam, W. F.; Darrel G. Schulze; J. B. Dixon (Ed.) Soil Mineralogy with Environmental Applications. v.1. Madison, New York, p.390-412.

RECEIVED: $27 / 09 / 2017$

ACCEPTED: 29/03/2018

ASSOCIATE EDITOR: José Stevaux 